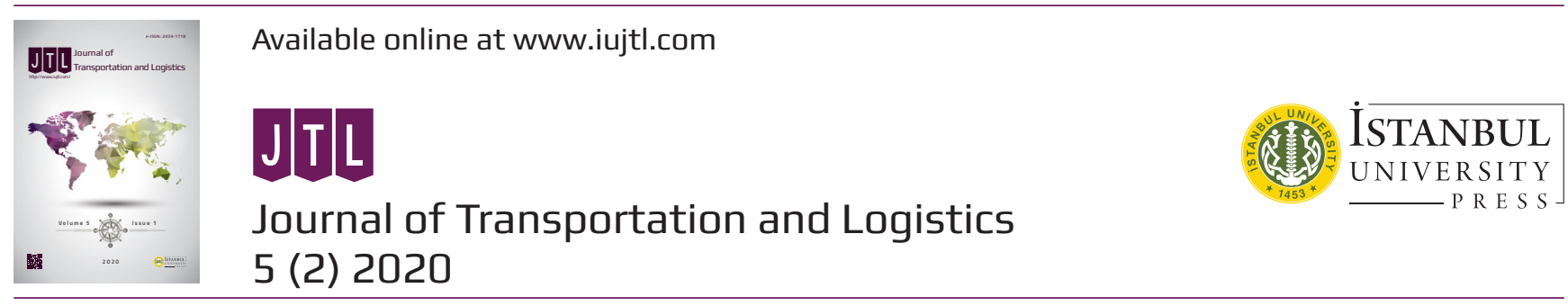

\title{
Airport Competitiveness Analysis from Aircraft and Passenger Movement
}

\author{
Fernanda Henriqueta Sabina de Moura ${ }^{1}$, Mauro Caetano² $^{(1)}$, Maico Roris Severino ${ }^{3}$ (1)
}

\begin{abstract}
Air transportation development is strictly related to airport competitiveness, since the airport management seeks to improve the capacity to produce services, increase passenger and aircraft movement, improve revenues from aeronautical and non-aeronautical activities, and optimise the other items related to the competitiveness of this type of organisation. In this sense, this study seeks to identify variables associated with the competitiveness of airports, based on their infrastructures, operations, and locations, which can influence the decision-making of airport managers continuously and efficiently. An analysis of the seven busiest Brazilian airports, in terms of aircraft and passenger movement, has been made, and multivariate data analysis has been used through a multiple regression, verifying the relationship between the variables of airports competitiveness, such as the total area of the airport site, number of aircraft parking positions, number of airlines, quantity of aircraft movementlandings and takeoffs, total number of passengers and the GDP of the city where the airport under study is located. The results present an index of competitiveness for each airport analysed after the data mathematical treatment, showing the coefficients at the general equations form aircraft and passenger movement.
\end{abstract}

Keywords: Air Transport, Competitiveness Index, Mathematical Modelling

1 Corresponding author: Fernanda Henriqueta Sabina de Moura, Federal University of Goiás (UFG), Transportation Engineering, MTOW: Research Group in Air Transport Innovation, Aparecida de Goiânia, GO-Brazil. E-mail: feernandamouraa@gmail.com, ORCID: 0000-0002-2903-6694

2 Mauro Caetano, Aeronautics Institute of Technology (ITA), Civil Engineering Department, MTOW: Research Group in Air Transport Innovation, São José dos Campos/SP-Brazil. E-mail: caetano@ita.br, ORCID: 0000-0002-5978-1054

3 Maico Roris Severino, Federal University of Goiás (UFG), Production Engineering, SPL: Research Group in Production Systems Engineering and Logistics, Aparecida de Goiânia/GO-Brazil. E-mail: maicororis@gmail.com, ORCID: 0000-0001-8102-8678

Citation: Moura, F.H.S., Caetano, M. \& Severino, M.R. (2020). Airport competitiveness analysis from aircraft and passenger movement. Journal of Transportation and Logistics, 5(2), 143-157. https://doi.org/10.26650/JTL.2020.0015 


\section{Highlights}

- The study presents the main variables associated with the competitiveness of airports;

- Case studies with seven of the busiest airports in Brazil have been analysed to identify a mathematical index related to its competitiveness;

- Variables such as the number of aircraft movements, total airport area, number of aircraft positions arranged at the airport, number of non-aeronautical establishments, number of airlines, passenger movement and the GDP ratio of the city where the airport is located were analysed with statistical instruments to identify the main impact at the airport performance.

\section{Introduction}

Air transportation efficiency is directly combined with the management conditions of infrastructure, including airport facilities. As one of the main components of the air transportation system, airports organisations must be effective and efficient in its core business, reaching competitive conditions to operate. According to Morrel (2016), airport competitiveness is linked to the attraction of airlines, and consequently their passengers, and other types of services, such as food, clothing, entertainment, car rental, etc.

It is noted that the airport is the first impression for a person landing at his or her final destination. For Carillho (2009), it is indisputable that air services are fundamental for society, for the value that the existence of an airport creates for the region where it is inserted, promoting the development of tourism, the employment sector, investments, taxes and regional development among others. With this, airports need to be competitive organisations to perform a critical role in economic development at local, national and international levels (Graham, 2004; Wiltshire, 2018).

The objective of this study is to identify and describe variables associated with the competitiveness of airports, as well as to perform a comparative analysis between the main Brazilian airports, making it possible for tourism destinations management to analyse, improve and innovate their definitions of service quality and competitiveness.

\section{Theoretical Basis}

To designate an airport as competitive, it is necessary to study and analyse these airport structures to know each competitive variable deeply and how the airport applies its strategies to obtain a final result on the existing competitive factors. Carilho (2009) states that one of the methodologies that can be applied to the resolution of competitive analysis in airports is one of the five competitive forces proposed by Porter (2004). In this proposal, the author analyses as a whole the threats of new participants in a given market or also possible threats of substitutes, the existing bargaining power of buyers and suppliers and the rivalry between existing organisations. 
The main competitive strategies defined by Porter (2004) are cost, leadership, differentiation and focus, as shown in Figure 1. These variables are considered in this study because each airport can have its differentiated type of competitive strategy, being able to provide products and services to a broader clientele or focus that supply specific customers. Therefore, Porter (1992) states that if an organisation follows any of these strategies, there is a great chance of success in the market.

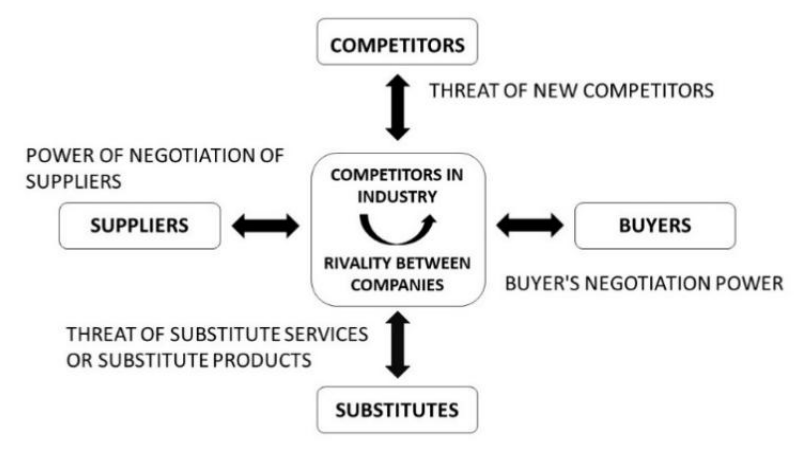

Figure 1. Demonstration of the five competitive forces

Source: adapted from Porter (1992)

In this strategic model discussed by Porter (2004), factors are analysed from all possible points, that is, everything that encompasses the organisation can serve as a benefit or not to the business strategy and must be analysed. The author explains that the competitive strategic variables of his model are the cost of goods and services, leadership in the market, as well as the differentiation in the market and the focus on a certain goal to be achieved.

Another type of analysis is proposed by Graham (2004) on airport management, and considers the amount of control or influence that an airport has over the two fundamental sources of competitive advantage: prices and products. The author demonstrates that the area where the airport has the greatest competitive advantage lies in its services and non-aeronautical facilities in the airport terminal. As it has the largest concentration of people and retail operators, their types of services are rendered to exploit to the maximum, non-aeronautical and commercial opportunities.

Regarding the aeronautical opportunities associated with the operating procedures at the airport, the amount of freedom that airports have in this area will depend on how much the government has direct control over the airport or the economic nature in which the airport works. This will also be influenced by the market power that the airline has. The ability of an airport to compete will also differ depending on which type of airline is being accommodated and its degree of price sensitivity (Graham, 2004)

For Wiltshire (2018), to discern whether or not an airport is subject to competitive pressures, its behaviour with prices, in this case, airport charges are analysed. There is evidence, for example, that airports that reduce rates may suggest that their prices are constrained by competitive pressure from competing airports, i.e., competing airports, which may or may not have greater power in the airport market can influence the change 
in rates at other airports. Airport charges are usually more influential for short-haul operations as they are charged more frequently.

Areas which airports have little or no control over and can reflect in little competitive advantage, can be exemplified as the availability of slots in an airport and its physical location. According to ANAC (2014), slots are the arrival or departure times allocated for the movement of an aircraft on a specific date at a given airport, and for planning, the time at which the aircraft arrives or leaves the terminal.

Regarding the physical structure of an airport, the factors that will determine the attractiveness of the location of the airport structure include the size of the population and its propensity to use air transport services, and the tourist's economic and commercial strength of the area (Favotto, 1998). It can be said that, to a large extent, airports concentrated in regions that do not have a local market focused on receiving tourists or with little demand for flights and passengers can be characterised as an airport with little prominence in a competitive position.

It should also be considered that airports operating short-haul flights have more competitors than those operating longer long-haul flights. Given that, according to ANAC (2016), demand for domestic flights is relatively higher than demand for international flights, taking into account the distance and duration of flights, existing customs conditions and airlines operating within the international airport structure among others.

Wiltshire (2018) states that the identification, treatment, and management of a competitive airport should be done on a case-by-case basis. Each airport has its individuality to be studied and considered by numerous factors that may or may not be competitive in the market.

The competitiveness of airports is not only linked to their location or their qualities of infrastructure. In Tretheway and Kincaid's (2005) report, factors that compose airport competition can be understood as the competition for serving a shared local market, traffic connections, freight traffic, destinations most demanded for a service, service nonaeronautical (retail, food and beverage, etc.), as well as competition with other modal types, such as rail, road and waterway.

McKinnon (2011) shows that the variables that participate in the competitiveness of airports are highlighted in location, i.e., airports closer to shippers have cost and time advantages, and airport infrastructure; such as lane capacity, terminal configuration and transport, choice and the quality of freight forwarders (international freight transport).

To ascertain the degree of competitiveness of an airport, it is necessary to evaluate the correlated infrastructure, the location of the airport by analysing the region in which it is located, from the level of regional development expressed by GDP, the number of connections between terminals, the size of the network of influence from the airport to the related locations and the airport infrastructure; such as courtyards, positions available for aircraft, aircraft movement, the number of existing airlines, billing generated and the projection of future revenues due to concessions. A summary of the main variables 
associated with the airport competitiveness identified in the literature is presented in Table 1.

Table 1. Summary of the main variables associated with airport competitiveness identified in the literature

\begin{tabular}{|c|c|c|c|}
\hline Authors & $\begin{array}{l}\text { Variables } \\
\text { considered }\end{array}$ & Area of application & Measurement form \\
\hline $\begin{array}{l}\text { Favotto } \\
(1998)\end{array}$ & $\begin{array}{c}\text { Airport } \\
\text { infrastructure: size } \\
\text { of airports }\left(\mathrm{m}^{2}\right)\end{array}$ & $\begin{array}{l}\text { Boarding and disembarking areas, } \\
\text { check-in, food court, stores, lobbies } \\
\text { and parking. }\end{array}$ & $\begin{array}{l}\text { Population size (the larger } \\
\text { the population, the greater } \\
\text { the use of air transport } \\
\text { services). }\end{array}$ \\
\hline \multirow{4}{*}{$\begin{array}{l}\text { McKinnon } \\
(2004)\end{array}$} & Airport location & $\begin{array}{l}\text { Airports located close to the shippers, } \\
\text { and / or easily accessible, have time } \\
\text { and cost advantages. }\end{array}$ & Time and cost. \\
\hline & $\begin{array}{c}\text { Airport } \\
\text { infrastructure: size } \\
\text { of airports }\left(\mathrm{m}^{2}\right)\end{array}$ & $\begin{array}{c}\text { Airports with more types of aircraft } \\
\text { offering a wider range of service } \\
\text { types. }\end{array}$ & $\begin{array}{c}\text { Track capacity, } \\
\text { track configuration, } \\
\text { transportation of terminals } \\
\text { as well as appropriate } \\
\text { facilities for freight } \\
\text { forwarders. }\end{array}$ \\
\hline & Airport fees & $\begin{array}{l}\text { It is commonly applied in air tickets } \\
\text { for airport maintenance. }\end{array}$ & Prices of airport charges. \\
\hline & $\begin{array}{l}\text { Environmental } \\
\text { restrictions }\end{array}$ & $\begin{array}{l}\text { Airports located very close to urban } \\
\text { centres, and in cities with severe } \\
\text { climate change. }\end{array}$ & $\begin{array}{l}\text { Population dissatisfaction } \\
\text { with noise, locations } \\
\text { suffering from mild climatic } \\
\text { events. }\end{array}$ \\
\hline $\begin{array}{l}\text { Graham } \\
(2004)\end{array}$ & Prices and products & $\begin{array}{l}\text { Airport management, non- } \\
\text { aeronautical services, trades } \\
\text { (shopping facilities). }\end{array}$ & $\begin{array}{l}\text { Revenue from services } \\
\text { rendered, revenues from } \\
\text { trade-in non-aeronautical } \\
\text { products. }\end{array}$ \\
\hline \multirow{3}{*}{$\begin{array}{l}\text { Tretheway } \\
\text { and Kincaid } \\
\text { (2005) }\end{array}$} & $\begin{array}{l}\text { Non-aeronautical } \\
\text { services }\end{array}$ & Non-aeronautical services. & $\begin{array}{l}\text { Revenues from retail sales, } \\
\text { food, clothing, etc. }\end{array}$ \\
\hline & Traffic connections & $\begin{array}{l}\text { Airports located on routes close } \\
\text { to each other compete for flight } \\
\text { connections. }\end{array}$ & $\begin{array}{l}\text { Number of connections for } \\
\text { same-destination flights. }\end{array}$ \\
\hline & $\begin{array}{l}\text { Competition with } \\
\text { other modal types }\end{array}$ & $\begin{array}{l}\text { Airports still compete with other } \\
\text { modes, even having a greater } \\
\text { advantage of time, such as modal rail, } \\
\text { road and waterway. }\end{array}$ & $\begin{array}{l}\text { Number of routes made } \\
\text { by other modes, distances } \\
\text { covered by other modes, } \\
\text { user sensitivity to the price } \\
\text { of other modes }\end{array}$ \\
\hline $\begin{array}{l}\text { Renzetti } \\
(2015)\end{array}$ & $\begin{array}{l}\text { Competition with } \\
\text { the local market }\end{array}$ & $\begin{array}{l}\text { More than one airport infrastructure } \\
\text { can be used in the same locality (e.g. } \\
\text { GRU and CGH airports), the local } \\
\text { market can influence the services } \\
\text { provided by airports. }\end{array}$ & $\begin{array}{l}\text { Quantity and variety } \\
\text { of services in the local } \\
\text { market that can influence } \\
\text { the services provided by } \\
\text { airports. }\end{array}$ \\
\hline $\begin{array}{l}\text { Wiltshire } \\
(2018)\end{array}$ & Airport fees & $\begin{array}{l}\text { Airport behavior regarding the } \\
\text { collection of aeronautical charges. }\end{array}$ & $\begin{array}{l}\text { Collection of aeronautical } \\
\text { charges. }\end{array}$ \\
\hline
\end{tabular}

As shown in Table 1, the main variables identified in the literature are related to airports operating daily. The airport's physical location can be described as variable of competitiveness in relation to other airports close by. It is believed that an airport can become competitive by supplying such variables and trying to outperform its competitors in the airport market. 


\section{Methods}

Multivariate statistical analysis data, using multiple regression, has been used to identify the variables that influence and make an airport competitive. A multivariate analysis of data is done when it is necessary to work simultaneously with several variables, in which there is no direct relation between them. That is, this method is used when there is a large grouping of data seeking to summarise and / or simplify the similar behaviour of them. It can be used and applied for several purposes even when there is no theoretical model that structures the relation of the variables operated (Bakke, Leite and Silva, 2008).

There are some types of techniques for obtaining a multivariate analysis of data, such as factorial analysis, regression and multiple correlation, multiple discriminant analysis, multivariate analysis of variance and covariance, and joint analysis among others. In this study, the multiple regression method has been used.

Multiple regression is characterised by a multivariate method of analysis that relates a single dependent variable to a set of independent variables. This indicates a high flexibility and adaptability, granting its use in almost every relation of dependence of variables. To perform a multiple linear regression, three main questions must be considered: (a) adjusting the problem to the research, (b) specifying the statistical relationship between the variables for the analysis and (c) selecting and specifying which are the dependent and independent variables to be analysed (Hair et al., 2009).

The study of the competitive variables was based on input and output factors in which inputs are related to input resources, inputs, or services in an organisation and the outputs are related to the results obtained by the input processing. For Graham (2008), these are the most relevant factors that define the performance of an airport.

The competitive criteria analysed at airports is based on their infrastructures, operations and locations. Thus, variables related to infrastructures (the total area of the airport site, number of aircraft parking positions and non-aeronautical establishments), to operations (the number of airlines, quantity of aircraft movement - landings and takeoff and the total number of passengers - domestic and international) and to airport's location (GDP of the city where the airport under study is located) were considered as independent variables (inputs). For the dependent variable (output), the operating variable corresponding to the annual aircraft movement (landings and takeoffs) was used for the first simulation, and the annual passenger movement for the second simulation to verify the behaviour of the variables for conditions.

All these variables were collected and treated in a comparative manner in the year 2016 between airports to define which of them could be considered as being competitive, according to the data obtained. The sample of this study is composed of the 7 largest Brazilian airports (AET, 2018): The São Paulo - Guarulhos International Airport (GRU), São Paulo - Congonhas Airport (CGH), Brasília International Airport (BSB), Rio de Janeiro - Galeão International Airport (GIG), Campinas - Viracopos Internacional Airport (VCP), Rio de Janeiro - Santos Dumont Airport (SDU), and Belo Horizonte - Confins International Airport (CNF). The main characteristics and variables considered for each airport studied are presented in Table 2. 
Table 2. Main airports variables considered

\begin{tabular}{|c|c|c|c|c|c|c|c|}
\hline \multirow[b]{2}{*}{ Airports } & \multirow{2}{*}{$\begin{array}{c}\begin{array}{c}\text { Operation } \\
\text { (Output) }\end{array} \\
\begin{array}{c}\text { Aircraft } \\
\text { movement } \\
\text { (thousands) }\end{array}\end{array}$} & \multicolumn{3}{|c|}{ Infrastructure (Input) } & \multicolumn{2}{|c|}{ Operation (Input) } & \multirow{2}{*}{$\begin{array}{l}\text { Location } \\
\text { GDP of the } \\
\text { city } \\
\text { (millions of } \\
\text { R\$) }\end{array}$} \\
\hline & & $\begin{array}{l}\text { Total area } \\
\qquad\left(\mathbf{m}^{2}\right)\end{array}$ & $\begin{array}{l}\text { Aircraft } \\
\text { parking } \\
\text { positions } \\
\text { (n) }\end{array}$ & $\begin{array}{c}\text { Non- } \\
\text { aeronautical } \\
\text { establishments } \\
\text { (n) }\end{array}$ & $\begin{array}{l}\text { Number } \\
\text { of } \\
\text { airlines } \\
\text { (n) }\end{array}$ & $\begin{array}{c}\text { Movement } \\
\text { of } \\
\text { passengers } \\
\text { (millions) }\end{array}$ & \\
\hline GRU & 267746 & 11905056 & 123 & 241 & 42 & 36596326 & 570.706 .192 \\
\hline CGH & 213043 & 1647000 & 55 & 150 & 8 & 20816957 & 570.706 .192 \\
\hline BSB & 161167 & 28995153 & 70 & 120 & 9 & 18564113 & 175362791 \\
\hline GIG & 125566 & 17881696 & 214 & 126 & 25 & 16103011 & 282538827 \\
\hline VCP & 115276 & 17659300 & 32 & 218 & 6 & 9325252 & 51347711 \\
\hline SDU & 105671 & 833703 & 13 & 156 & 5 & 906988 & 282538827 \\
\hline CNF & 99422 & 15010000 & 43 & 33 & 11 & 9638798 & 81426708 \\
\hline
\end{tabular}

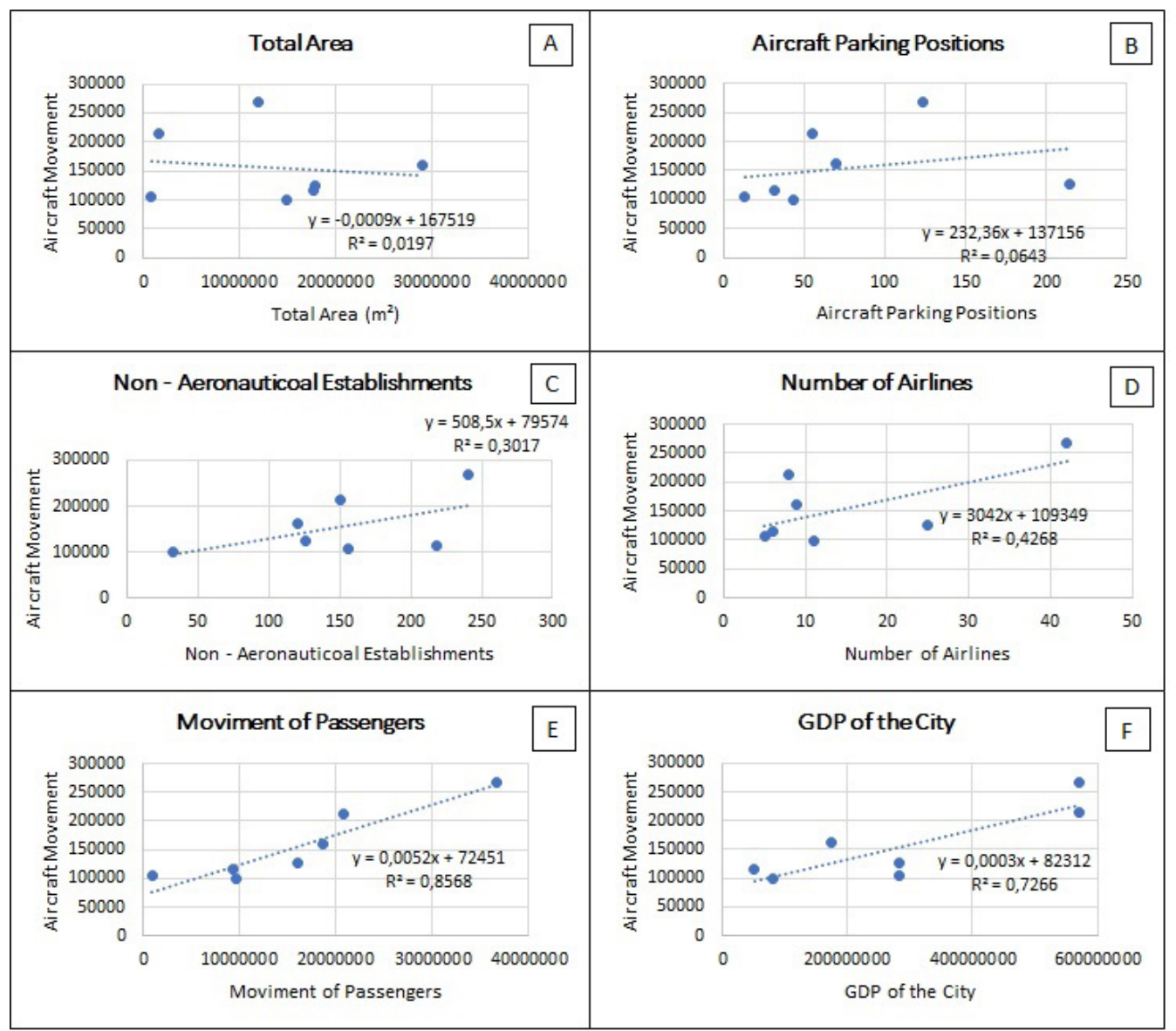

Figure 2. Relation of independent variables to the dependent variable

In which: A - scatter plot and line of a linear trend between the total area and the aircraft movement; B - scatter plot and linear trend line between the number of parking lots and the movement of aircraft; C - scatter plot and linear trend line between the number of non-aeronautical establishments and the movement of aircraft; D - scatter plot and linear trend line between the number of airlines and the movement of aircraft; E - dispersion chart and trend line between the movement of passengers and the movement of aircraft; F - graph of dispersion between the GDP of the city and

the movement of aircraft.

Source: search data 
To conduct the study of how the competitive variables chosen are related to the dependent variable, dispersion graphs were plotted with linear trend lines. It can be seen from Figure 2 that few independent variables can be linearly related to the dependent variable.

According to Figure 2, whenever the value of $\mathrm{R}^{2}$ is close to 1 or equal to 1 , it means that the variables are linearly related. The independent variables that are related in a linear way to the dependent variable (aircraft movement) are: passenger movement (Figure 2-E) and city GDP (Figure 2-F). For this reason, few dependent variables relate to the independent variable linearly, the analysis made takes into account that the distribution is non-linear and the methodology used becomes specific for this group of selected variables.

The coefficients of each of the competitiveness variables of each airport were identified. Equations 1 and 2 were used as a reference in the multiple regression and, in a comparative way, the independent variables were used with a single dependent variable. Thus, it is assumed that the independent variables are not linearly related to the dependent variable. In Equation 1, $D$ correspond to the dependent variable, $X, Y, Z \ldots$ to the independent variables, and $a, \beta, \gamma \ldots$ the coefficients.

$$
D=X^{\alpha} \times Y^{\beta} \times Z^{\gamma} \times \ldots
$$

Applying the $\ln$ on both sides of the Equation 1, the Equation 2 was obtained for the multiple regression.

$$
\begin{gathered}
\ln D=\ln \left(X^{\alpha} \times Y^{\beta} \times Z^{\gamma} \ldots\right) \\
\ln D=\ln X^{\alpha}+\ln Y^{\beta}+\ln Z^{\gamma}+\ldots \\
\ln D=\alpha \times \ln X+\beta \times \ln Y+\gamma \times \ln Z+\cdots
\end{gathered}
$$

Thus, it becomes possible to apply the multiple regression for the determination of parameters $a, \beta$ and $\gamma$.

\section{Data analysis}

From the identification of the In values of the competitive airports' variables, the corresponding values are presented in Table 3 .

Table 3. Value corresponding to the natural logarithms of the competitive airports' variables

\begin{tabular}{|l|c|c|c|c|c|c|c|}
\hline Airports & $\begin{array}{c}\text { Aircraft } \\
\text { movement }\end{array}$ & $\begin{array}{c}\text { Total } \\
\text { area }\end{array}$ & $\begin{array}{c}\text { Aircraft } \\
\text { parking } \\
\text { positions }\end{array}$ & $\begin{array}{c}\text { Non- } \\
\text { aeronautical } \\
\text { establishments }\end{array}$ & $\begin{array}{c}\text { Number of } \\
\text { airlines }\end{array}$ & $\begin{array}{c}\text { Movement of } \\
\text { passengers }\end{array}$ & $\begin{array}{c}\text { GDP of } \\
\text { the city }\end{array}$ \\
\hline GRU & 12,498 & 16,292 & 4,812 & 5,485 & 3,738 & 17,415 & 20,162 \\
\hline CGH & 12,269 & 14,314 & 4,007 & 5,011 & 2,079 & 16,851 & 20,162 \\
\hline BSB & 11,990 & 17,183 & 4,248 & 4,787 & 2,197 & 16,737 & 18,982 \\
\hline GIG & 11,741 & 16,699 & 5,366 & 4,836 & 3,219 & 16,595 & 19,459 \\
\hline CNF & 11,507 & 16,524 & 3,761 & 3,497 & 2,398 & 16,081 & 18,215 \\
\hline SDU & 11,568 & 13,634 & 2,565 & 5,050 & 1,609 & 13,718 & 19,459 \\
\hline VCP & 11,655 & 16,687 & 3,466 & 5,384 & 1,792 & 16,048 & 17,754 \\
\hline Source: search data (2016) & \multicolumn{7}{|l|}{} \\
\hline
\end{tabular}


After obtaining the values corresponding to the $\ln$ of the variables, the analysis was then adopted by multiple regression, and the Table 4 shows the parameters returned by the regression.

Table 4. Multiple regression analysis

\begin{tabular}{|c|c|}
\hline \multicolumn{2}{|c|}{ Summary of results } \\
\hline \multicolumn{2}{|c|}{ Regression Statistics } \\
\hline R multiple & 0,99999999 \\
\hline R - square & 0,99999998 \\
\hline R - square adjusted & $-1,15 \mathrm{E}-07$ \\
\hline Standard error & 0,00435618 \\
\hline Note & 7 \\
\hline Source: search data & \\
\hline
\end{tabular}

In analysing Table 4 (multiple regression), in which the values of $R$ vary from 0 to 1 , it is observed that the regression model can explain the values found. It means that, the higher the values of $R$, or the closer to 1 , the better it fits the sample. According to the $R$-squared found, it can be noted that $99 \%$ of the dependent variables can be explained by the regressors (independent variables raised by their coefficients). Table 5 shows the coefficients returned by the multiple regression performed.

Table 5. Coefficients returned by multiple regression

\begin{tabular}{|l|c|c|}
\hline Variable & Nomenclature & Coefficient \\
\hline Total area & $T_{\text {area }}$ & 0,0896 \\
\hline Aircraft parking positions & $n_{\text {parking }}$ & $-0,3604$ \\
\hline Non-aeronautical establishments & $n_{\text {estab }}$ & 0,1258 \\
\hline Number of Airlines & $n_{\text {airlines }}$ & 0,0722 \\
\hline Aircraft movement & $A_{\text {mov }}$ & 0,2849 \\
\hline GDP of the city & $G D P$ & 0,3398 \\
\hline Source: search data & & \\
\hline
\end{tabular}

From the values presented in Table 5, Equation 3 presents the mathematical representation of these results for the dependent variable aircraft movement (Amov) .

$A_{\text {mov }}=\frac{T_{\text {area }}{ }^{0,0896} \times n_{\text {estab }}{ }^{0,1258} \times n_{\text {airlines }}{ }^{0,0722} \times P_{\text {mov }}{ }^{0,2849} \times G D P^{0,3398}}{n_{\text {parking }}{ }^{0,3604}}$

It is worth noting that the variables that are inversely proportional to the dependent variable must be interpreted differently from the others, since there is an inconsistency in exposing that a larger "aircraft parking number" returns a smaller contribution to the "aircraft movement". This is due to the multiple regression process, which aims to adjust the values of the database to a general equation.

After the manipulation of the values through the multiple regression, the values referring to the aircraft movement were determined, which are the values referring to the dependent 
variables of each airport. These values are described in Table 6, together with the percentage of error that the equation accompanies after the estimation of the values. The error is calculated by the actual value module minus the estimated value, divided by the actual value. The error was calculated to demonstrate that the error percentage of the estimated value for this dependent variable is low.

Table 6. Estimated value for the dependent variable (aircraft movement) and their respective errors $(\%)$

\begin{tabular}{|l|c|c|}
\hline Airports & Estimated value by Equation & Error (\%) \\
\hline GRU & 267516,36 & 0,09 \\
\hline CGH & 213132,89 & 0,04 \\
\hline BSB & 160607,31 & 0,35 \\
\hline GIG & 125753,02 & 0,15 \\
\hline CNF & 99516,16 & 0,09 \\
\hline SDU & 105663,85 & 0,01 \\
\hline VCP & 115470,58 & 0,17 \\
\hline Source: search data & & \\
\hline
\end{tabular}

The next step was to apply each variable to its respective exponent separately, as shown in Table 7.

\begin{tabular}{|c|c|c|c|c|c|c|}
\hline Airports & Total area & $\begin{array}{l}\text { Aircraft } \\
\text { parking } \\
\text { positions }\end{array}$ & $\begin{array}{c}\text { Non-aeronautical } \\
\text { establishments }\end{array}$ & $\begin{array}{l}\text { Number of } \\
\text { airlines }\end{array}$ & $\begin{array}{c}\text { Movement of } \\
\text { passengers }\end{array}$ & $\begin{array}{l}\text { GDP of } \\
\text { the city }\end{array}$ \\
\hline GRU & 4,3070 & 0,1765 & 1,9935 & 1,3097 & 142,7483 & 944,0950 \\
\hline CGH & 3,6073 & 0,2359 & 1,8780 & 1,1619 & 121,5550 & 944,0950 \\
\hline BSB & 4,6648 & 0,2163 & 1,8261 & 1,1719 & 117,6530 & 632,2675 \\
\hline GIG & 4,4670 & 0,1446 & 1,8373 & 1,2615 & 112,9815 & 743,4940 \\
\hline CNF & 4,3974 & 0,2578 & 1,5524 & 1,1890 & 97,6147 & 487,1977 \\
\hline SDU & 3,3938 & 0,3968 & 1,8873 & 1,1232 & 49,7877 & 743,4940 \\
\hline VCP & 4,4620 & 0,2868 & 1,9685 & 1,1381 & 96,6994 & 416,5538 \\
\hline
\end{tabular}

For the final analysis and the competitive airports ranking, a competitive index was established of the division of the variables in Table 7 by the highest value of these. After that, the sum of these was made for each airport, finally having a competitiveness index for each one.

For the variable that is related inversely proportional to the dependent variable returned by the regression, an adjustment of its contribution to the competitiveness index was made. In this sense, to obtain a coherent value, the value 1 (one) was subtracted. That is to say that a larger number of aeronautical establishments would return a greater contribution to the competitiveness index, for example, if value 1 (one) was subtracted.

Thus the values obtained are consistent, since for example, the larger the number of 
non-aeronautical establishments, the greater is the contribution to the competitiveness index (according to Table 8).

Table 8. Index of competitiveness of the airports studied

\begin{tabular}{|l|c|c|c|c|c|c|c|}
\hline Airports & $\begin{array}{c}\text { Total } \\
\text { area }\end{array}$ & $\begin{array}{c}\text { Aircraft } \\
\text { parking } \\
\text { positions }\end{array}$ & $\begin{array}{c}\text { Non-aeronautical } \\
\text { establishments }\end{array}$ & $\begin{array}{c}\text { Number of } \\
\text { airlines }\end{array}$ & $\begin{array}{c}\text { Movement of } \\
\text { passengers }\end{array}$ & $\begin{array}{c}\text { GDP of } \\
\text { the city }\end{array}$ & $\begin{array}{c}\text { Competitivity } \\
\text { index }\end{array}$ \\
\hline GRU & 0,9233 & 0,5551 & 1,0000 & 1,0000 & 1,0000 & 1,0000 & 5,4784 \\
\hline CGH & 0,7733 & 0,4054 & 0,9421 & 0,8872 & 0,8515 & 1,0000 & 4,8595 \\
\hline BSB & 1,0000 & 0,4549 & 0,9160 & 0,8948 & 0,8242 & 0,6697 & 4,7596 \\
\hline GIG & 0,9576 & 0,6356 & 0,9217 & 0,9632 & 0,7915 & 0,7875 & 5,0571 \\
\hline CNF & 0,9427 & 0,3502 & 0,7787 & 0,9078 & 0,6838 & 0,5160 & 4,1793 \\
\hline SDU & 0,7275 & 0,0000 & 0,9468 & 0,8576 & 0,3488 & 0,7875 & 3,6682 \\
\hline VCP & 0,9565 & 0,2772 & 0,9875 & 0,8690 & 0,6774 & 0,4412 & 4,2088 \\
\hline Source: search data & & & & & & \\
\hline
\end{tabular}

According to Table 8, the results confirm Porter's (1992) competitive analysis tool that states the five competitive forces that should be explored by organisations seeking competitive advantages. This is also supported by Carrilho (2009). Following Porter's five forces and analysing the results, an airport should always analyse its competitors to stand out or seek to improve its strategies for the cost and differentiation of its services, market leadership and to focus its attitudes to makes it more competitive. Analysing this way, good administration can contribute to the increase of all the indexes indicated in the study and consequently, to the increase of the competitiveness index of an airport.

Another argument supported by the study was that of Graham (2008), stating that the airports that have the greatest competitive advantage are those that have a great influence on non-aeronautical services at the airport terminal, where retail business opportunities exist and a greater number of people are present. This rationale can be seen in Table 8, where the highest competitiveness figures for airports are concentrated in the variable of non-aeronautical establishments. It is worth mentioning that this study also supports the Wiltshire (2018) statement, where each airport has individual characteristics and should be analysed on a case-by-case basis, since they may have different competitive variables.

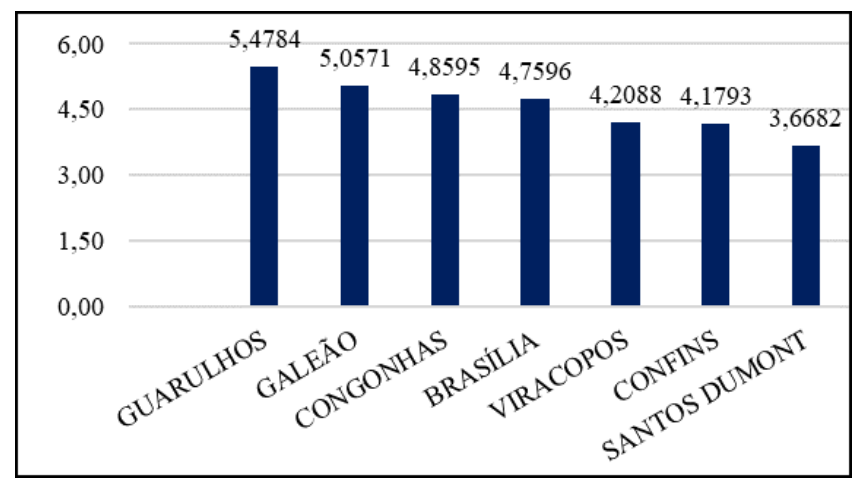

Figure 3. Competitiveness indexes - aircraft movement

Source: search data 
It can be seen in Table 8 that the highest indices belong to GRU airport, and Figure 3 shows the ranking of the competitive airports studied according to the variables analysed for the variable chosen as dependent: aircraft movement.

To simulate the case of a commercial airport to value more by the quantity of passengers than by the quantity of aircraft, a new simulation was performed in which it considered the movement of passengers (Pmov) as a dependent variable. The entire process described in the previous sections was performed again to obtain Equation 4 and Figure 4 as results.

$P_{\text {mov }}=\frac{n_{\text {parking }}{ }^{1,2651} \times A_{\text {mov }}{ }^{3,5101}}{T_{\text {area }}{ }^{0,3146} \times n_{\text {estab }}{ }^{0,4415} \times n_{\text {airlines }}{ }^{0,2534} \times G D P^{1,1925}}$

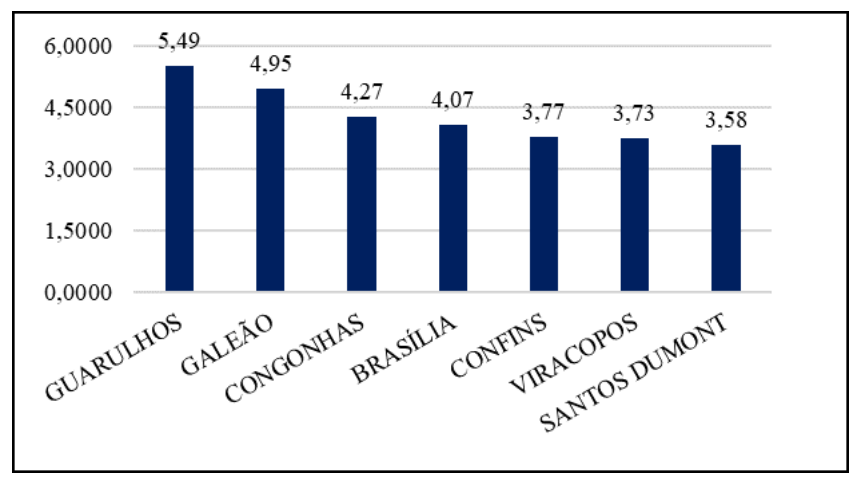

Figure 4. Competitiveness Index - movement of passengers

Source: search data

In Figure 4, a small change in the ranking of airports is noted. The change in this ranking can be affirmed for the reason that in this index, CNF simulation has a greater movement of passengers, and in the previous simulation, VCP has a greater movement of aircraft (passengers + loads). However, it is noted that by comparing airports, the distances between their indexes vary, once again concluding that airports have different characteristics and should be analysed on a case-by-case basis as Wiltshire (2018) states. Taking as an example BSB airport, it can be concluded that the difference between the competitiveness indexes obtained by the two simulations is because the airport has, in this case, a high cargo movement.

\section{Final considerations and future studies}

Considering the results obtained, this study allowed a competitive comparison by a multivariate analysis of data from Brazilian airports, some of them managed by Infraero and others administered by their respective private concessionaires, offering a partial perspective on the subject.

The difficulty of choosing variables and obtaining their data justifies the option to work with a non-linear distribution and the use of the methodology presented in this study. 
It was possible to identify an incoherence when using the non-linear distribution method of the independent variables with the dependent variable. When performing the multiple regression process, for a variable dependent on the aircraft movement, the coefficient related to the number of negative non-aeronautical establishments was obtained. However, this does not necessarily show that this factor is not linked to airport competitiveness. This is because some independent variables chosen are not linearly related to the dependent variable. This can be seen at the plots with a linear trend line, according to Figure 2. It was possible to notice that the independent variables are linearly related to the dependent variable, and have a greater influence on the composition of the competitiveness indexes.

The study of variables considered competitive in airports, serves to make visible how much the airport sector can be considered to have an impact within a country, and shows how it can be related to the economy, organisational culture, the number of services and strategic location among factors. And with this, the study can serve a purpose in the forecasting, researching and implementation and of improvements, while always considering the need for constant innovation and user satisfaction.

According to the ranking of airports and their respective competitiveness indexes, it is noted that GRU presented the highest competitiveness index between the airports practiced for both analyses. On the other hand, SDU presented the worst competitiveness index. This does not necessarily mean or points to this airport as being bad or insufficient compared to others, but may be because this airport is located in the same city as GIG, which, having a larger portfolio of final destinations for flights and, consequently, greater passenger movement, is classified as being international.

It is also verified that the two simulations allowed to visualise the variation of the indexes obtained since the airports were analysed differently. This is because airports have different characteristics, that is, even if they are more or less valued by the movement of aircraft and by the movement of passengers, the indexes will always have variations.

As a suggestion for future studies, it is recommended to analyse a greater number of airports in the country and to compare them with airports in other parts of the world. Environmental issues, regional differences, cultures, policies and demands for aeronautical services should be taken into consideration and it should be decided upon which factors would be relevant to the Brazilian airport sector to further develop and influence the progress of this sector.

The discovery of independent variables that are linearly related to the dependent variable allows a better analysis of how they contribute to the composition of the dependent variable. In this sense, further investigation of the criteria established for each airport (infrastructure, operation, location) would allow a better analysis of the contribution of each of these parameters.

Another analysis that would be beneficial for future studies would be an application of airport benchmarking, where indexes of all the airports are analysed to quantify and to identify the competitive positions of each one. In this way, an airport listed as uncompetitive has the study of what to apply for improvements in its airport management and thus the opportunity to change its indexes mainly by improving management, the 
quality of the way its services are provided and the operational capacity of the airport. This benchmarking application is widely performed in the international environment and due to the scarcity of aeronautical studies in Brazil, this study would be also applicable to analysing international airports, not only Brazilian airports.

Peer-review: Externally peer-reviewed.

Conflict of Interest: The author has no conflict of interest to declare.

Grant Support: National Council for Scientific and Technological Development (CNPQ) and The State of Goiás Research Foundation (FAPEG).

Acknowledgement: National Council for Scientific and Technological Development (CNPQ), The State of Goiás Research Foundation (FAPEG) and the MTOW: Research Group in Air Transport Innovation.

\section{References}

AET. (s.d.). Ministério dos Transportes, Portos e Aviação Civil. Acesso em 09/07/2018 de Junho de 2018, disponível em www.transportes.gov.br: http://www.transportes.gov.br/images/2017/Sum\%C3\%A1rio_ Executivo_AET_-_2010_-_2016.pdf

ANAC. (2014). Resolução $n^{\circ} 338$ de 22 de julho de 2014. Agência Nacional de Aviação Civil, Brasília.

Bakke, H. A., Leite, A. S., \& Silva, L. B. (2008). Estatística multivariada: aplicação da análise fatorial. Revista Gestão Industrial, 04(04), 01-14.

Balter, T. S. (2012). Análise comparativa dos aeroportos brasileiros de grande porte a nível internacional. Dissertação (Mestrado) - UFRJ/ COPPE/ Programa de Engenharia de Transportes, Rio de Janeiro.

BNDES. (Agosto de 2001). Infra-estrutura aeroportuária: fator de competitividade econômica. Informe Infra-Estrutura.

Carilho, P. A. (2009). Estratégias competitivas de captação de companhias low cost. Dissertação (Mestrado em Engenharia Civil) - Instituto Superior Técnico, Universidade Técnica de Lisboa, Lisboa.

Confederação Nacional da Indústria (CNI). (2014). Avaliação do trasporte público piora de 2011 a 2014.

Empresa Brasileira de Infraesttutura Aeroportuária. (2018). Aeroportos.

Favotto, I. (1998). Not all airports are created equal. Airport World.

Graham, A. (19-20 de November de 2004). Airport strategies to gain competitive advantage. gars: slots, airport competition and benchmarking of airports. University of Westminster, Bremen.

Graham, A. (2008). Managing airports: an international perspectives ( $3^{\mathrm{a}} \mathrm{ed}$.). Oxford: Butterworth-Heinemann.

GRU AIRPORT. (2016). Informações operacionais. Fonte: https://www.gru.com.br/pt/institucional/ informacoes-operacionais

Guarulhos, A. I. (2016). GRU AIRPORT. Acesso em 15 de 07 de 2018, disponível em https://www.gru.com.br/

Hair, J. F., Black, W. C., Babin, B. J., Anderson, R. E., \& Tatham, R. L. (2009). Análise multivariada de dados ( $6^{\mathrm{a}}$ ed.). Bookman.

McKinnon, A. (2011). The air cargo industry and transhipment in hong kong: challenges, opportunities and global competitiveness. City University of Hong Kong, Hong Kong.

Morrel, P. (2016). Airport competition and network access: a european perspective. Em P. Forsyth, D. Gillen, J. Müller, \& H.-M. Niemeier, Airport Competition: The European Experience (pp. 11-26). London and New York: Routledge Tyalor \& Francis Group.

Porter, M. E. (1992). Vantagem competitiva: criando e sustentando um desempenho superior. Rio de Janeiro: Campus.

Porter, M. E. (2004). Estratégia competitiva: técnicas para análise de indústria e da concorrência. Rio de Janeiro: Campus. 
Renzetti, B. P. (Novembro de 2015). Concessões e concorrência nos aeroportos brasileiros . Revista de Defesa da Concorrência, 3.

Souza, A. L. (2010). Análise comparativa do desempenho de aeroportos a nível mundial utilizando Conceitos $D E A$. Dissertação (Mestrado) - COPPE/ UFRJ/ Programa de Engenharia de Produção, Rio de Janeiro.

Tretheway, M., \& Kincaid, I. (2005). Concorrência entre aeroportos do novo milênio: o que funciona, o que não funciona e por que? $8^{a}$ Conferência de Aviação de Hamburgo.

Wiltshire, J. (2018). Airport competition: reality or myth? Journal of Air Transport Management, 67, 241-248. 
